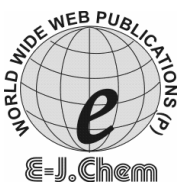

http://www.e-journals.net
ISSN: 0973-4945; CODEN ECJHAO

E-Journal of Chemistry

Vol. 5, No.3, pp.557-561, July 2008

\title{
Chemical Composition of the Essential Oil From the Aerial Parts of Artemisia Herba
}

\author{
A. NEZHADALI*, M. AKBARPOUR ${ }^{*}$ and B. ZARRABI SHIRVAN $\$$ \\ *Dept. of Chemistry, Payam-Noor University of Mashhad, Mashhad-Iran. \\ \#Dept. of Chemistry, Payam-Noor University of Bojnourd, Bojnourd-Iran. \\ ${ }^{\$}$ ID 31330, Medical Organization of Mashhad, Mashhad, Iran. \\ aziz_nezhadali@yahoo.com
}

Received 3 August 2007; Revised 20 September 2007; Accepted 17 October 2007

\begin{abstract}
The aerial parts of the plant artemisia herba were collected in the May 2007 from Babaaman (North Khorassan Province of Iran). The plant was isolated by hydro distillation. A total of 61 constituents, representing more than $98 \%$ of the oil were identified by gas chromatograph/mass spectrometry (GC/MS). The main compounds, were alpha-pinene $(3.28 \%)$, champhene $(4.8 \%)$, sabinen $(5.18 \%)$, beta-myrcene (3.04), cis, beta-terpineol (11.31\%), camphor (6.11\%), 8-hydroxylinalool (2.64\%), L-4-terpineol ( $2.5 \%)$, alpha- therpineol (2.33\%), myrtenol (3.27\%), bornyl acetate $(6.2 \%)$, alpha-terpinol acetate $(3.06 \%)$, germacrene $(2.06 \%)$, davanone $(8.49 \%)$, trans-farnesol (4.27\%), cis-fernesol $(2.07 \%)$ and 1,3,dicyclopentyl cyclopentane $(2.29 \%)$. This herbal medicine traditionally uses as antiinfectious, anti-bacterial, emmenagogue, parasiticide, digestive and stomachic and gastric tonic in Iran.
\end{abstract}

Keywords: Artemisia herba, Essential oil, GC/MS, Hydro distillation, Medicine

\section{Introduction}

Artemisia is fairly large genuses within the family of the Asteraceae (compositeate) with 200 individual species are usually found in dry areas ${ }^{1-4}$. They are invariably found as small fragment shrubs or herbs and most yield essential oils. Some of these oils have found uses in perfumery and medicine ${ }^{5-7}$. Artemisia species are reported to possess anti-diabetic effect and have been used in many countries of middle east and Iran as a herbal medicine for treatment of diabetes, high blood pressure, anti-migraine, anti-fungal activity, digestive, anti-helminic, useful as tonic, antihelninic, azulene source, mycolytic, stomachic, anti-bacterial, lipolytic, anti-septic, good source of chamazulene, vermifuge, and mucolytic ${ }^{8-13}$. Because of application of Artemisia in traditional medicine, many species of this genus have been 
surveyed by phytochemists and pharmacologists ${ }^{14-18}$. On the other hand, many species in compositeate family have been found that have effective ingredients in medicinal projects ${ }^{19-21}$. One of the important species is Artemisia herba (A. herba). In our present work, the chemical compositions of $A$. herba are identified by using aerial part of the dried plant. Artemisia herba were collected from Babaaman Mountain, North Khorassan Province of Iran in May 2007. After one week drying the plant in shadow place, the dried plant was used for our experiments.

\section{Experimental}

Aerial parts of wild growing A. herba were collected in May 2007 from Bojnourd (Northern Khorassan Province of Iran). It was air dried in a shadow place. The dried plant was powdered and the essential of it was isolated by hydrodistillation for $4 \mathrm{~h}$. The oil was dried over anhydrous sodium sulfate and stored at $4^{0} \mathrm{C}$.

\section{Essential Oil Analysis}

The essential oil was analyzed by GC/MS. The GC/MS analysis was carried out on a Shimadzu GC/MS model QP 5000. The capillary column was BD-5(30x0.2mm, film thickness $0.32 \mu \mathrm{m})$. The operating conditions were as follows; carrier gas, helium with a flow rate of 1.7 $\mathrm{mL} / \mathrm{min}$; column temperature, injector and detector temperatures, was both at $280^{\circ} \mathrm{C}$; volume injected $0.1 \mu \mathrm{L}$ of the essential oil and ionization potential 70ev. The initial temperature of column was $60^{\circ} \mathrm{C}$ (held $2 \mathrm{~min}$ ) and then heated to $200^{\circ} \mathrm{C}$ with a $3^{\circ} \mathrm{C} / \mathrm{min}$ rate and then heated to $240^{\circ} \mathrm{C}$ and kept constant for $2 \mathrm{~min}$. The same condition of temperature programming used for $n$-alkenes mixture to calculate the RI. Determination of the oil percent in the plant obtained $(1.19 \mathrm{w} / \mathrm{w} \%)$. Identification of components in the oil was based on the similarity Index (SI), retention index (RI). The relative percentage of the oil constituents was calculated.

\section{Results and Discussion}

A. preliminary study on the chemical compositions of essential oils of $A$. herba growing in North Khorassan, Iran, was conducted. The yield of oil is quiet low, only about $1.19 \mathrm{w} / \mathrm{w} \%$. The oil is yellow with odor characteristic of plant. The hydrodistillation time for $50 \mathrm{~g}$ of dried A. herba is $4 \mathrm{~h}$. Chromatogram of the analysis is shown in Fig.1. The total ion chromatogram (TIC) retention time is about $45 \mathrm{~min}$. The most compositions of the oil isolates around the first $20 \mathrm{~min}$ of the analysis procedure and condition. The qualitative and quantitative analytical results are show in Table 1. A total of 61 components were identified by GC/MS, representing $98 \%$ of the oil.

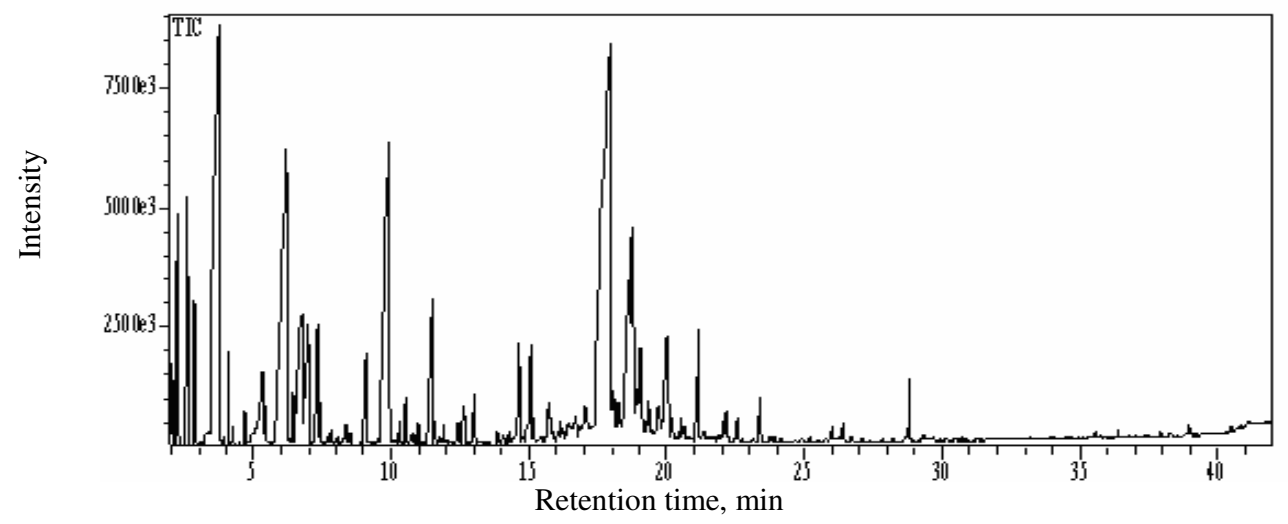

Figure 1. The chromatogram of $A$. herba essential oil. 
Table 1. Variation of essential oil composition of Artemisia herba, collected from North Korassan, Iran and analyzed by GC/MS.

\begin{tabular}{|c|c|c|c|c|}
\hline No. & Composition & *RI & SI\% & $\begin{array}{l}\text { Percentage } \\
\text { in the oil }\end{array}$ \\
\hline $1^{\mathrm{a}}$ & alpha-Pinene & 989 & 95 & 3.28 \\
\hline 2 & Champhene & 1005 & 92 & 4.8 \\
\hline 3 & Sabinen & 1011 & 92 & 5.18 \\
\hline 4 & beta-Myrecen & 1016 & 92 & 3.04 \\
\hline 5 & Cyclohexene-4-methyl- 3-(1-methylethylidene) & 1027 & 91 & 0.22 \\
\hline 6 & cis -beta - Terpineol & 1056 & 90 & 11.31 \\
\hline 7 & 3-Octyn-2ol & 1060 & 86 & 0.07 \\
\hline 8 & Oxcimene & 1063 & 91 & 0.15 \\
\hline 9 & Terpinolene & 1095 & 90 & 0.71 \\
\hline 10 & beta-Linalool & 1108 & 85 & 0.18 \\
\hline 11 & Camphor & 1160 & 87 & 6.11 \\
\hline 12 & beta- Linalool & 1170 & 84 & 1.08 \\
\hline 13 & 8-Hydroxy linalool & 1179 & 80 & 2.64 \\
\hline 14 & L-4-Terpineol & 1180 & 87 & 2.50 \\
\hline 15 & alpha-Thujenal & 1190 & 86 & 0.29 \\
\hline 16 & alpha- Therpinol & 1202 & 86 & 2.23 \\
\hline 17 & Myrtenol & 1200 & 83 & 3.27 \\
\hline 18 & (E)-3(10)-Caren-2-ol & 1220 & 85 & 0.26 \\
\hline 19 & cis-Carveol & 729 & 80 & 0.11 \\
\hline 20 & (E)-3(10)-Caren-4-ol & 1242 & 81 & 0.35 \\
\hline 21 & $S$-Carvone & 1248 & 82 & 0.22 \\
\hline 22 & Pinocarvyl acetate & 1268 & 83 & 1.85 \\
\hline 23 & Bornyl acetate & 1296 & 92 & 6.2 \\
\hline 24 & Neryl acetate & 1299 & 90 & 0.25 \\
\hline 25 & 2,6-Dimethyl-3,5,7- octatriene-2-ol & 1311 & 82 & 0.47 \\
\hline 26 & Terpin diacetate & 1320 & 82 & 0.98 \\
\hline 27 & Myrcenyl acetate & 1327 & 88 & 0.25 \\
\hline 28 & 5-Bromo-1-hexene & 1331 & 86 & 0.22 \\
\hline 29 & Gama -Elemene & 1337 & 88 & 2.43 \\
\hline 30 & alpha- Therpinol acetate & 1356 & 80 & 2.43 \\
\hline 31 & Pivalonate & 1359 & 80 & 0.48 \\
\hline 32 & cis-Carvyl acetate & 1366 & 82 & 0.18 \\
\hline 33 & Nerol acetate & 1371 & 88 & 0.44 \\
\hline 34 & iso Borneol propionate & 1376 & 88 & 0.11 \\
\hline 35 & Geranyl acetate & 1389 & 88 & 0.43 \\
\hline 36 & Dihydrocarveol acetate & 1397 & 81 & 0.81 \\
\hline 37 & beta-Farnesene & 1412 & 89 & 1.25 \\
\hline 38 & alpha-Ergamotene & 1405 & 82 & 0.24 \\
\hline 39 & Farnesyl alcohol & 1454 & 80 & 0.16 \\
\hline 40 & $\begin{array}{l}\text { 5-Hepten-3-one,2-[5-ethenylterahydro-5- } \\
\text { methyl-2- furanyl]-6-methyl }\end{array}$ & 1466 & 82 & 0.14 \\
\hline 41 & Germacrene D & 1476 & 91 & 2.06 \\
\hline
\end{tabular}




\begin{tabular}{|c|c|c|c|c|}
\hline 42 & alpha-Bisabolene epoxide & 1494 & 83 & 1.56 \\
\hline 43 & Davana ether & 1515 & 85 & 1.28 \\
\hline 44 & delta-Cadinene & 1591 & 88 & 0.6 \\
\hline 45 & Limonen-6-ol, pivalate & 1538 & 83 & 0.27 \\
\hline 46 & Hedycaryol & 1545 & 85 & 0.35 \\
\hline 47 & Lilac alcohol & 1556 & 80 & 0.52 \\
\hline 48 & Davanone & 1563 & 92 & 8.49 \\
\hline 49 & Caryophyllene oxide & 1571 & - & 0.72 \\
\hline 50 & $\begin{array}{l}\text { Spiro[2,3]hexane-5-carboxylic acid, } \\
\text { 1-methyl,menthyl ether }\end{array}$ & 1621 & 83 & 0.8 \\
\hline 51 & trans-Fernesol & 1642 & 94 & 4.27 \\
\hline 52 & 2-Octylcyclopropene-1-heptanol & 1653 & 85 & 1.86 \\
\hline 53 & Jatamansone & 1667 & 86 & 0.81 \\
\hline 54 & Cis -Z- alpha-Bisabolene epoxide & 1680 & 84 & 0.73 \\
\hline 55 & cis-Fernesol & 1693 & 84 & 2.07 \\
\hline 56 & Lilacaldehyde & 1722 & 83 & 0.31 \\
\hline 57 & Ethyl linalool & 1730 & 84 & 0.1 \\
\hline 58 & 1,3-Dicyclopentylcyclopentane & 1746 & 82 & 2.29 \\
\hline 59 & $1,6,9$, tetra decatriene & 1807 & 84 & 0.41 \\
\hline 60 & Cetylic acid & 1970 & 94 & 0.27 \\
\hline $61^{\mathrm{b}}$ & Trans-phytol & 2109 & 91 & 1.18 \\
\hline
\end{tabular}

*Retention Index; ${ }^{* *}$ Similarity Index; ${ }^{a}$ Composition with the lowest retention time

${ }^{b}$ Composition with the highest retention time

cis, beta-Terpineol (11.31\%) was determined as the first major constituent in the oil, the second was davanone (8.49\%) and the third bornyl acetate (6.2\%). The other major compositions were camphor $(6.11 \%)$, sabinen $(5.18 \%)$, champherne (4.8\%), trans-farnesol $(4.27 \%)$, alphapinene $(3.28 \%)$, myrtenol $(3.27 \%)$, alpha-terpinol acetate (3.065), beta-myrcene $(3.04 \%)$, 8-hydroxylinalool (2.64\%), L-4-terpineol (2.5\%), alpha-therpineol (2.33\%), 1,3,dicyclopentyl cyclopentane (2.29\%), cis-fernesol (2.07\%) and germacrene (2.06\%) in the oil, respectively. Fig. 2 shows the compositions with amount more than $2 \%$ in the oil.

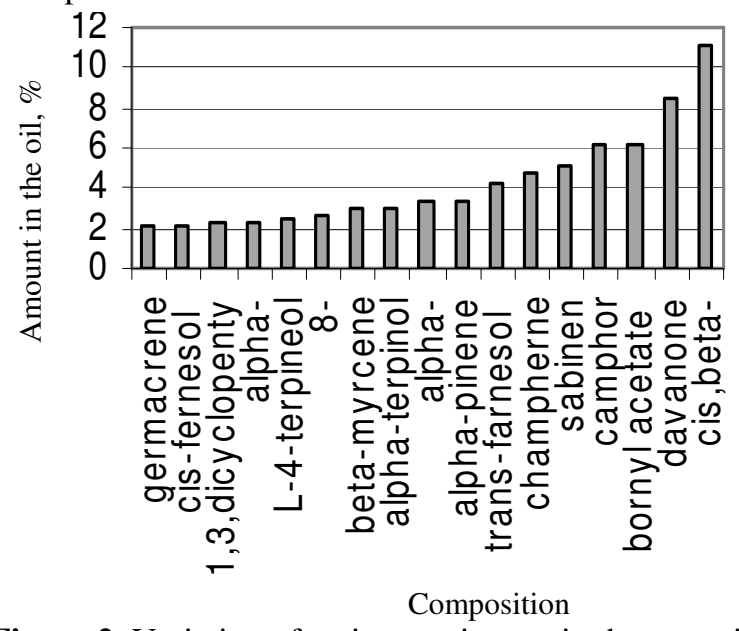

Figure 2. Variation of main constituents in the essential oil of A. herba. 
The results show that the second major composition is davanone in the oil. As it is reported in the literature ${ }^{4}$, one of the main compositions in A. herba is davanone. The presence of davanone in the plant makes it as anti-infectious, antibacterial, paraticide ${ }^{4}$. This plant traditionally uses for the mentioned properties of it and some other effects like as gastric tonic, digestive and stomachic medicine in Iran.

\section{Acknowledgments}

The authors thank Research Council of Payam-Noor University for financial support.

\section{References}

1. Singh A, Kaul V K, Marlrajan V P, Imsra I N, Thakur and R S, Husain A, Indian J. Pharm. Sci. 1986, 5, 137.

2. Thapa R K, Indian J. Pharm. 1968, 30, 283.

3. Rekka E A, Kouronnakis A P and Kouronnakis P N, Res. Com. Mol. Parmacel. 1996, 92, 361.

4. Yashphe J, J. Pharm. Sci. 1979, 68, 924.

5. Mueller M S, Karhayomba I B, Hirt H M and Wemakor E, J. Ethropharmacology, 2000, 73, 487.

6. Kim K S, Lee S, Hung S H, Park Y and Shin K H, J. Ethnopharmacology, 2003, 85, 69.

7. Marrif B H and Hassan A K M, J. Ethnopharmacology, 1995, 49, 51.

8. Sheppard Hanger S, The Aromatherapy Practitioner Referance Manual, 1995.

9. Gundidza M, J. Fitoterapia,. 1986, 57,111.

10. Thakur R S, Misra, L N, Essential oils of India artemisia $11^{\text {th }}$ Int. congress of essential oils fragrances and flavours, New Delhi, 1989.

11. Mabberly D J, The Plant book, Cambridege University Press, 1993.

12. Rustaiyan A, Ameri N, Mirjalili B F, Mazloum Ardakani M, Hakimi. Maybody M and Bamoniri, Am. J. Sci. 2003, 48, 1074.

13. Twaij H A and Al-Badr A, J. Ethnopharmacology, 1988, 24, 123.

14. Charlson A J, J. Ethnopharmacology, 1980, 2, 323.

15. Mc Gaw L J, Lager A K and Van Staden J V, J. Ethnopharmacology, 2000, 72, 247.

16. Weenen $\mathrm{H}$, Nkunya $\mathrm{M} \mathrm{H} \mathrm{H}$, Bray $\mathrm{D} \mathrm{H}$, Mwasumloi L B, Kinabo $\mathrm{L} \mathrm{S}$ and Kilimali V A, Planta Medica. 1990, 56, 368.

17. Graven E, Deans S, Mavi S, Gudidza M G and Svoboda K P, Flavour and Fragranle, J. 1992, 7, 121.

18. Salah S M and Jager A K, J. Ethnopharmacology, 2005, 99, 145.

19. Vonwiller P C, Haynes R K, King G and Wang H, Planta Med. Lett. 1993, 59,546.

20. Mehmet M, Davut M, Hatice G and Fusun B, J. Cell and Molecular Biology, 2006, 5, 19.

21. Mossa J S, Fitoterapia, 1985, 56, 311. 


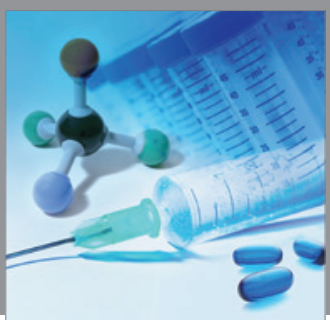

International Journal of

Medicinal Chemistry

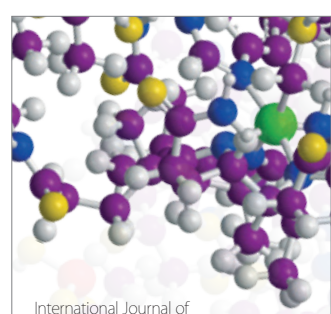

Carbohydrate Chemistry

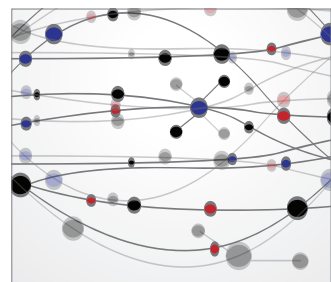

The Scientific World Journal
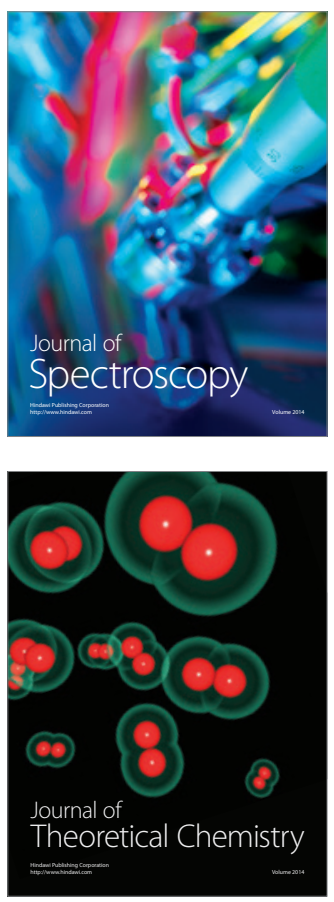
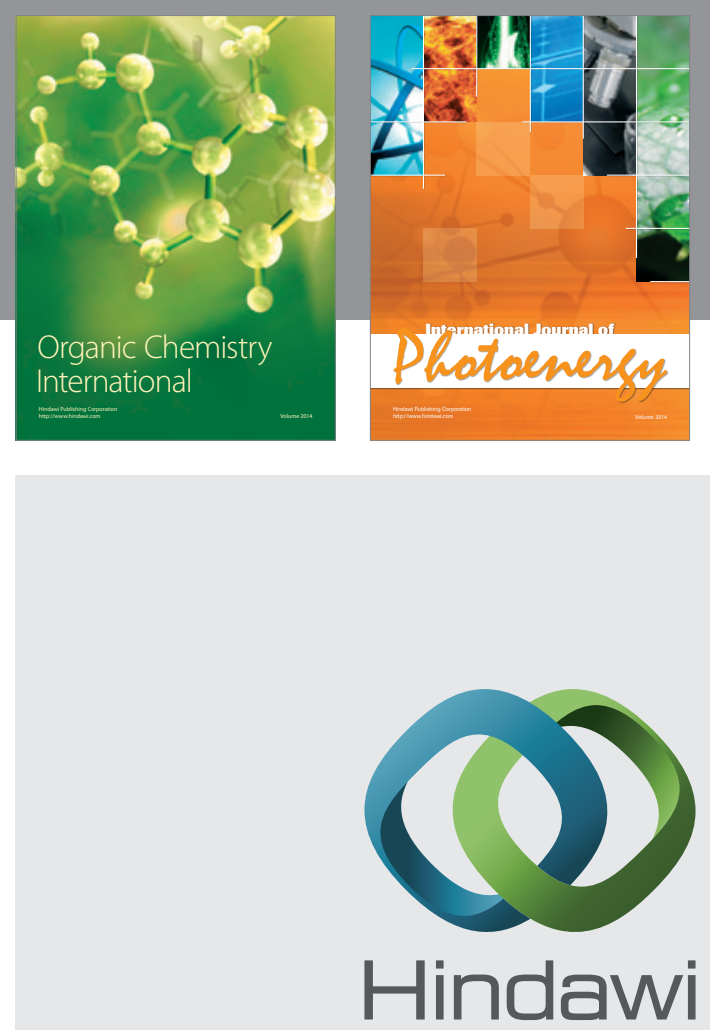

Submit your manuscripts at

http://www.hindawi.com
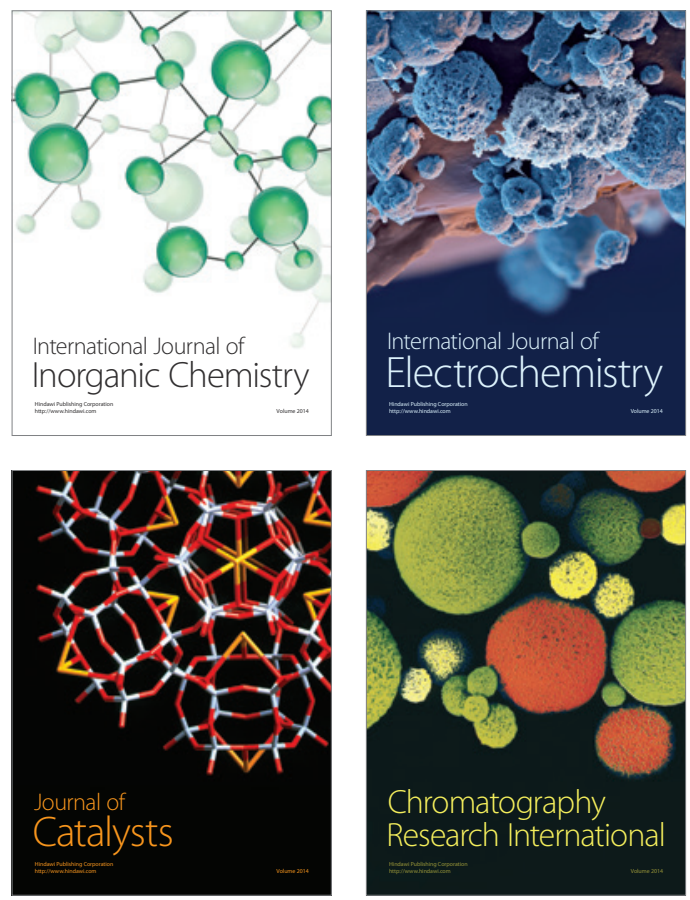
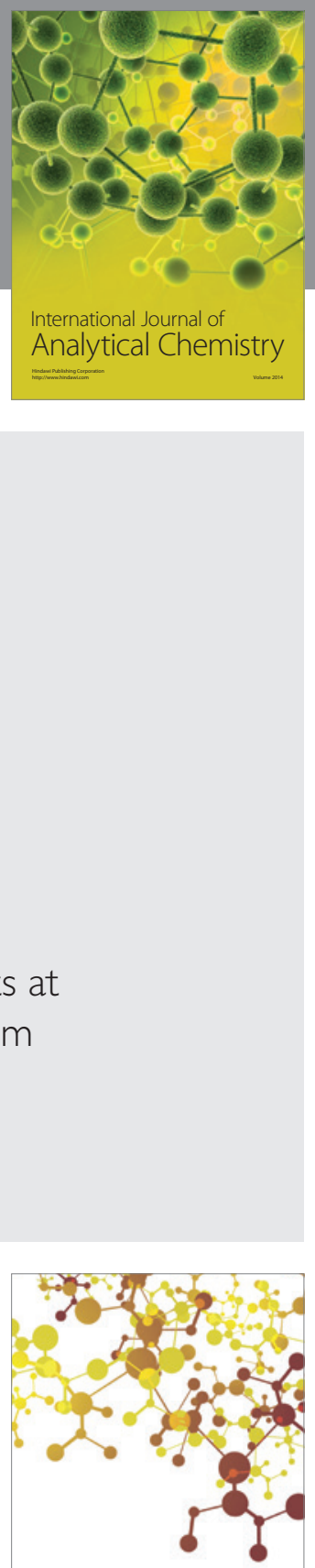

Journal of

Applied Chemistry
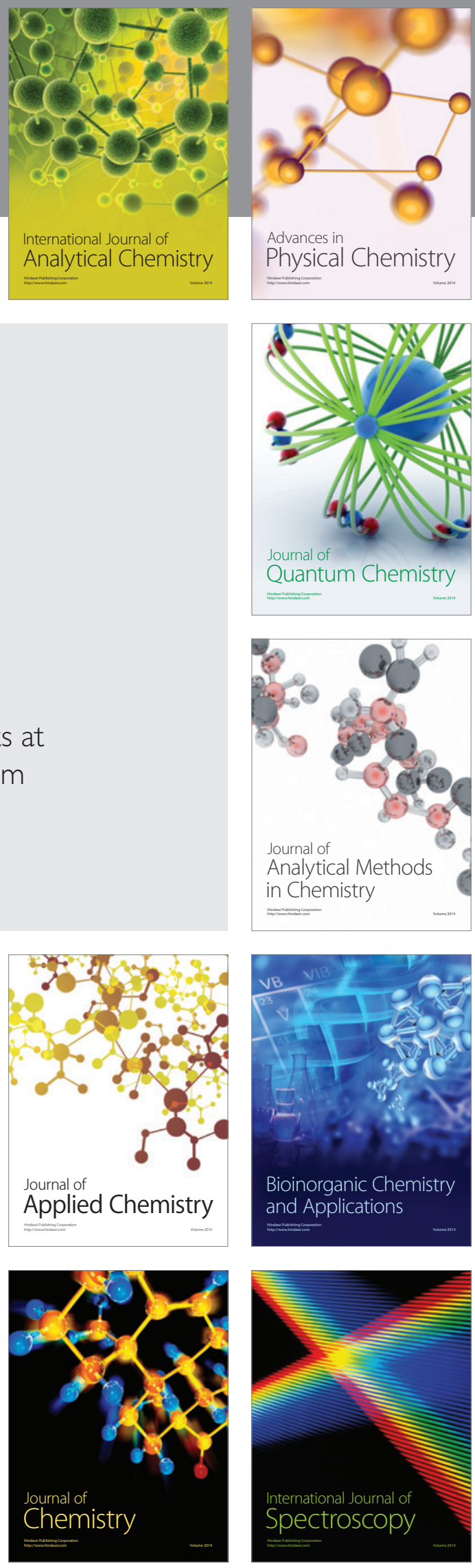